\title{
Relación entre la abundancia y biomasa de fitoplancton y bacterioplancton heterotrófico en aguas superficiales del Golfo de Arauco, Chile
}

\author{
Mireya Abarzúa R., Silvia Basualto M. y Homero Urrutia B. \\ Universidad de Concepción \\ Casilla 156-C, Concepción, Chile
}

\begin{abstract}
RESUMEN. Se analiza la relación entre la abundancia (concentración de células) y biomasa fitoplanctónica con la bacteriana, en la zona adyacente a la desembocadura del río Bío-Bío en el Golfo de Arauco, Chile. Para estimar la abundancia y biomasa bacteriana total, de bacterias heterótrofas aeróbicas recuperables y del fitoplancton, se realizaron muestreos en marzo (verano) y agosto (invierno) de 1991. Los resultados indican que la abundancia del fitoplancton presenta una correlación significativa con la abundancia y biomasa de bacterias heterotróficas, a diferencia de lo que ocurre con las mismas variables del total de bacterias. Se encontró una alta correlación de la abundancia de algas fitoplanctónicas y bacterias heterotróficas con la temperatura, parámetro que explica un alto porcentaje de las variaciones temporales observadas.
\end{abstract}

Palabras claves: relación, fitoplancton, bacterioplancton, superficial, Golfo de Arauco.

\section{Relation between count and biomass of phytoplankton and heterotrophic bacterioplankton in superficial water of Arauco Gulf, Chile}

\begin{abstract}
This work analize the relationships between the standing crop and biomass of phytoplankton and bacteria in the zone of the Arauco Gulf, Chile. Samples were taken during the month of march (summer) and august (winter) of 1991. The number and biomass of total bacteria, of aerobic heterotrophic bacteria, and of the phytoplankton were studied. The results show that the number of phytoplankton has a positive correlation with the number and biomass of the heterotrophic bacteria, but not with the total bacteria. There is also a high correlation with temperature, justifying the temporal variations noted in the results.
\end{abstract}

Key words: relation, phytoplankton, bacterioplankton, superficial, Arauco Gulf.

\section{INTRODUCCION}

Existen antecedentes que indican que las bacterias y el fitoplancton compiten por los nutrientes inorgánicos en aguas marinas; al mismo tiempo, la liberación de materia orgánica por parte del fitoplancton estimula la incorporación de compuestos carbonados y nutrientes en las comunidades bacterianas heterotróficas (Fuhrman, 1991).

La productividad primaria en ambientes acuáticos está dada principalmente por el fitoplancton, representando el primer eslabón de la trama trófica. Sin embargo, también es de primordial importancia la productividad de las bacterias y su actividad en la recirculación de los nutrientes (Barcina et al., 1992).
Barcina et al. (1992) encontraron que la producción bacteriana consumida por flagelados varía entre 16,5 y $33 \%$ en aguas marinas costeras. Por otra parte, Coveney (1982) estimó que el 50\% de la productividad bacteriana se basa en productos provenientes de las algas; mientras que Iturriaga y Zsolnay (1983) establecieron que el 30\% del material excretado por el fitoplancton circula a través de bacterias heterótrofas. Se deduce entonces, que la base del desarrollo de la biota de un ecosistema acuático está dada por la presencia del fitoplancton y bacterioplancton, y sus relaciones, tanto a nivel de la trama trófica (productores) como en la circulación de los elementos en el sistema (actividad degradadora) . 
Las aguas del Golfo de Arauco se caracterizan por presentar una alta productividad, siendo el área que soporta gran parte de las pesquerías artesanales e industriales de la VIII Región. También se encuentran importantes concentraciones de especies de moluscos, crustáceos y algas de importancia ecológica y económica (Arrizaga et al., 1991).

Dada la importancia de conocer el flujo del carbono en el Golfo de Arauco, se ha realizado este trabajo en la zona adyacente a la desembocadura del río Bío-Bío. Esto con el objeto de establecer las relaciones de abundancia y biomasa entre fitoplancton y bacterioplancton, posibilitando así una mejor interpretación del flujo de éste en las microbiocenosis que habitan las aguas superficiales.

\section{MATERIALES Y METODOS}

\section{Area de muestreo}

El trabajo se realizó en el Golfo de Arauco, en una superficie de aproximadamente $490 \mathrm{~km}^{2}$ adyacente a la desembocadura del río Bío-Bío, delimitada entre los $36^{\circ} 45^{\prime}$ y $36^{\circ} 55^{\prime} \mathrm{S}$, y $\operatorname{los} 73^{\circ} 10^{\prime}$ y $73^{\circ} 25^{\prime} \mathrm{W}$ (Fig. 1). En ésta se distribuyeron 6 estaciones (indicadas con los números $3,5,8,12,16$ y 18), que se muestrearon en marzo y agosto de 1991.

\section{Análisis del fitoplancton}

El análisis cuantitativo del fitoplancton se realizó a través de muestras superficiales recolectadas con botellas oceanográficas de tipo Universal (HydroBios). Las muestras fueron fijadas en una solución de lugol y analizadas en laboratorio siguiendo la técnica de Utermöhl (1958). El recuento del fitoplancton se realizó con un microscopio invertido (Zeiss, Modelo Axiovert 35), utilizando cámaras de sedimentación de 25 y 50 cc.

El cálculo de los biovolúmenes se realizó utilizando fórmulas geométricas relacionadas con la forma de la célula. Se realizó un mínimo de 10 medidas para cada especie, a partir de las cuales se obtuvo el valor del volumen medio, el que fue usado para calcular la biomasa asumiendo un peso específico de $1 \mathrm{~g} / \mathrm{cm}^{3}$.

\section{Análisis del bacterioplancton}

Las muestras microbio lógicas fueron tomadas en

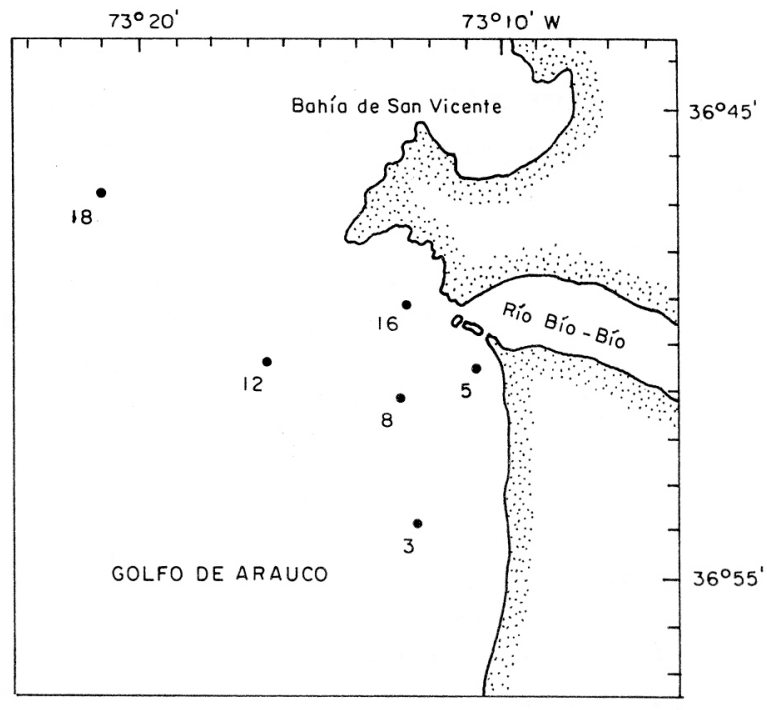

Figura 1. Ubicación de las estaciones de muestreo en el área de estudio.

frascos de vidrio estériles, transportadas bajo refrigeración y procesadas antes de 5 horas. La abundancia total de bacterias se determinó por microscopía de epifluorescencia, utilizando un microscopio Zeiss (Modelo Axioplan). Para tal efecto se fijó parte de la muestra con formalina estéril y $0,5 \mathrm{ml}$ de ella se tiñó con 0,2 ml de 4'6-diamino-2 fenil-indol (DAPI) (10 $\mathrm{mg} / \mathrm{ml}$ ). Luego se filtró mediante una membrana de policarbonato negra (Nucleopore) de 0,2 $\mu \mathrm{m}$ de tamaño del poro y se realizaron los recuentos bacterianos. A partir de las fotos se determinó el volumen celular promedio y se calculó la biomasa total de bacterias mediante la siguiente fórmula (Fry, 1988):

$$
\begin{gathered}
\text { Biomasa }(\mathrm{fgC})=\text { Abundancia } * \\
\text { Volumen celular promedio }\left(\mu \mathrm{m}^{3}\right) * 308\left(\mathrm{fg} C / \mu \mathrm{m}^{3}\right)
\end{gathered}
$$

Los recuentos de bacterias heterotróficas se realizaron sembrando alícuotas de las muestras, en la superficie de placas con agar marino, las que se incubaron a $20^{\circ} \mathrm{C}$ por 5 días, contándose aquellas placas que presentaron entre 30 y 300 colonias.

\section{Análisis físicos y químicos}

Los análisis considerados en este estudio fueron de temperatura, oxígeno, amonio, nitrato y fosfato. La cuantificación de estos parámetros se realizó de acuer- 
do a las metodologías de la American Public Health Association (1980), Parsons et al. (1984) y UNEP (1988).

\section{Tratamiento de los datos}

Para determintlr el efecto del tiempo y el espacio en la abundancia y productividad bacteriana y fitoplanctónica se utilizó el análisis de varianza, empleando como parámetro el $\log _{10}$ de cada variable. El grado de asociación de estas variables con los parámetros abióticos se analizó a través del modelo de regresión lineal simple y de regresión múltiple (Sokal y Rholf, 1988).

\section{RESULTADOS}

Las variaciones de los recuentos bacterianos y de fitoplancton se muestran en las Figs. 2, 3 y 4. De acuerdo con esta información, en los recuentos bacterianos totales no se observan grandes variaciones entre ambos períodos, alcanzando una media aproximada de $1 \times 10^{10}$ cél/l tanto en marzo como en agosto (Fig. 2). En cambio, el recuento de bacterias heterótrofas mostró diferencias entre ambos meses, variando de $3,4 \times 10^{7}$ cél/1 en marzo a 4,6 x $10^{5}$ ufc/l en agosto (Fig. 3). Esta variación se hace notable al analizar la abundancia fitoplanctónica en ambos períodos, ya que en marzo se observa una abundancia de al menos dos órdenes de magnitud mayor que en agosto (Fig. 4).

La biomasa bacteriana total no muestra diferencias en ambos meses, registrando una media de 1,73 mgC/l (1,73 x $10^{12}$ fgC/l) (Fig. S). En cambio, la biomasa de bacterias heterótrofas obtenidas de los recuentos es más alta en marzo (Fig. 6). Lo mismo ocurre con la biomasa fitoplanctónica, la que resultó mucho mayor en marzo, con la excepción de las estaciones 16 y 18 que corresponden a las más alejadas de la influencia del río Bío-Bío (Fig. 7).

La Tabla 1 resume la correlación entre las distintas variables biológicas registradas en el área de trabajo durante el período de estudio. Las mayores correlaciones se obtienen entre la abundancia de fitoplancton y la abundancia de bacterias heterotróficas $(r=0,79)$, y entre la abundancia de fitoplancton y la biomasa de bacterias heterotróficas $(\mathrm{r}=0,85)$.

El análisis de regresión entre los recuentos de bacterias heterótrofas y de fitoplancton se muestra en la Fig. 8. Se observa que el modelo de regresión lineal estimado es significativo, indicando que el $62 \%(p=0,002)$ del recuento de bacterias heterotróficas es explicado por las variaciones del recuento de fitoplancton. El resultado del mismo análisis para la biomasa de estas dos comunidades dio un coeficiente de determinación significativo igual al 54\% ( $\mathrm{p}=0,05)$ (Fig. 9).

Las variables químicas analizadas presentaron valores más altos en el muestreo de marzo que en el de agosto. Especialmente notorio es el caso del fosfato, el cual fluctuó entre 1,0 y 1,5 $\mu \mathrm{mol} / 1$ en marzo, y entre 0,3 y $0,5 \mu \mathrm{mol} / 1$ en agosto. Se repite esta misma tendencia en los valores de temperatura observados.

La influencia de variables ambientales sobre la abundancia y biomasa bacteriana y fitoplanctónica, en aguas superficiales del Golfo de Arauco, se muestra en la Tabla 2. Por otra parte, el análisis de regresión múltiple utilizando los parámetros físicos y químicos como variables independientes se muestra en las Tablas 3 y 4 . Finalmente, en la Fig. 10 se presenta la razón entre la biomasa del fitoplancton y la biomasa de bacterias heterotróficas en los dos meses de muestreo. Esta razón fluctuó entre 1 en la estación 8 durante agosto y 2,5 en la estación 18 en el mismo mes.

\section{DISCUSION}

El modelo de regresión entre la abundancia del fitoplancton y los recuentos de bacterias heterotróficas aeróbicas (Fig. 8), indica que existe un grado significativo de asociación $(\mathrm{p}=0,002)$ entre ambas variables, sugiriendo que la abundancia del fitoplancton influye en la abundancia de bacterias heterotróficas. De la misma manera se observa este tipo de asociación entre las biomasas bacteriana y fitoplanctónica ( $p=0,05$; Fig. 9). En cada caso se produce un aumento de los valores en marzo. Sin embargo, no ocurre 10 mismo entre las abundancias fitoplanctónicas y bacterianas totales; en este caso se observa una correlación inversa (Tabla 1).

En ambos casos (Figs. 8 y 9), los puntos observados se agrupan en tomo al modelo lineal dentro del intervalo de confianza del 90\%, separándose en dos grupos asociados al período de muestreo. Esto sugiere que, aunque el comportamiento general refleja una interdependencia de ambas comunidades, 


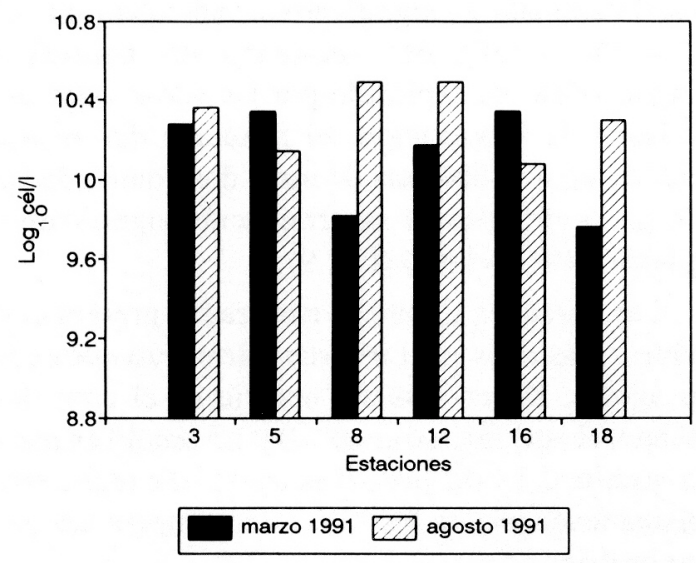

Figura 2. Recuentos bacterianos totales por estación de muestreo y mes.

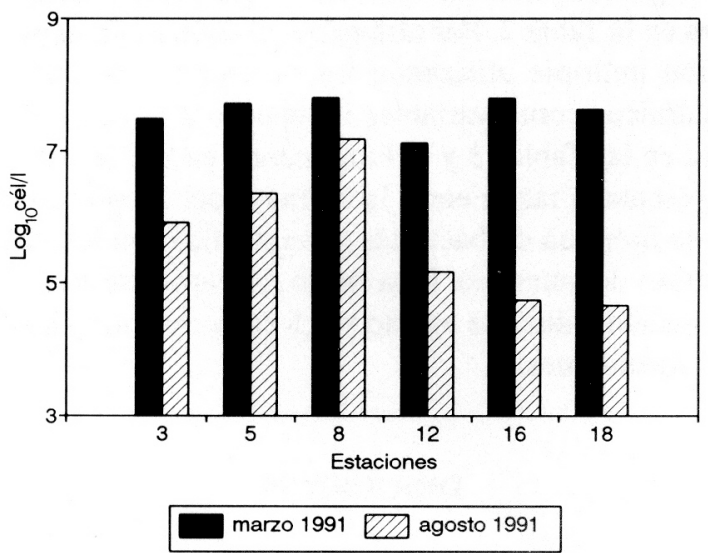

Figura 3. Recuentos de bacterias aeróbicas heterotróficas por estación de muestreo y mes.

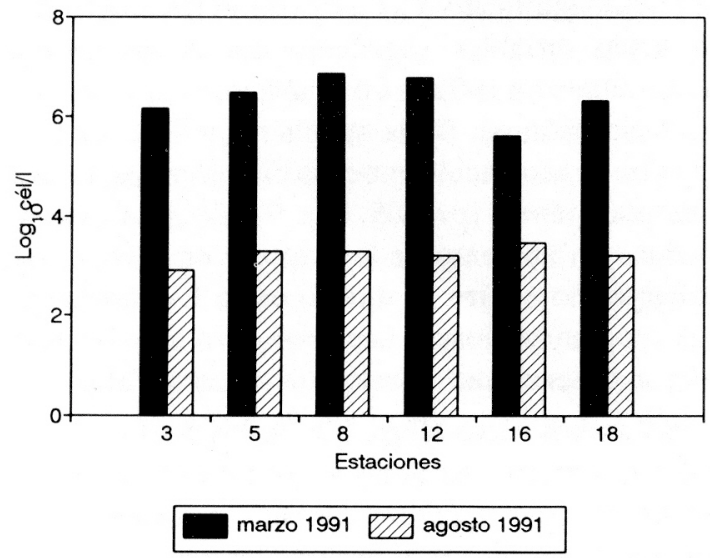

Figura 4. Abundancia superficial de fitoplancton por estación de muestreo y mes.

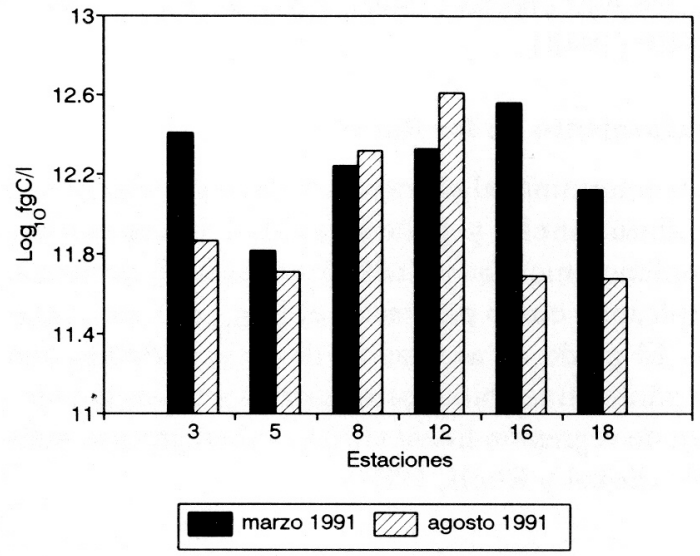

Figura 5. Biomasa bacteriana total por estación de muestreo y mes.

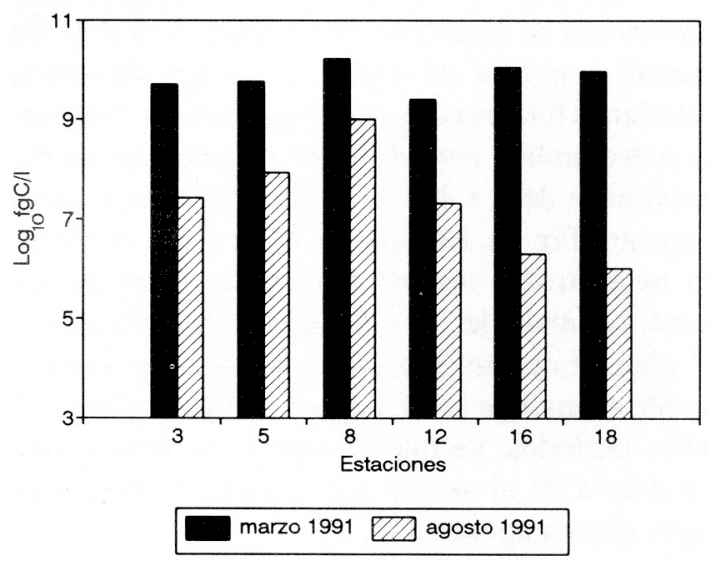

Figura 6. Biomasa de bacterias aeróbicas heterotróficas por estación de muestreo y mes.

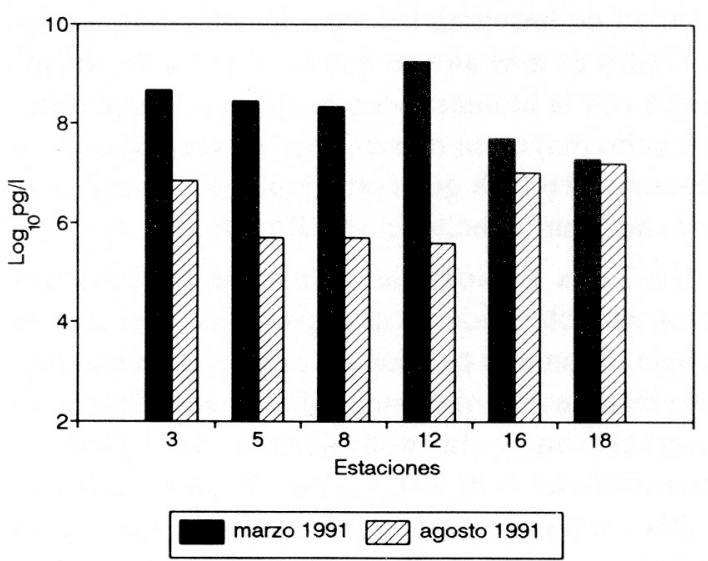

Figura 7. Biomasa de fitoplancton superficial por estación de muestreo y mes. 


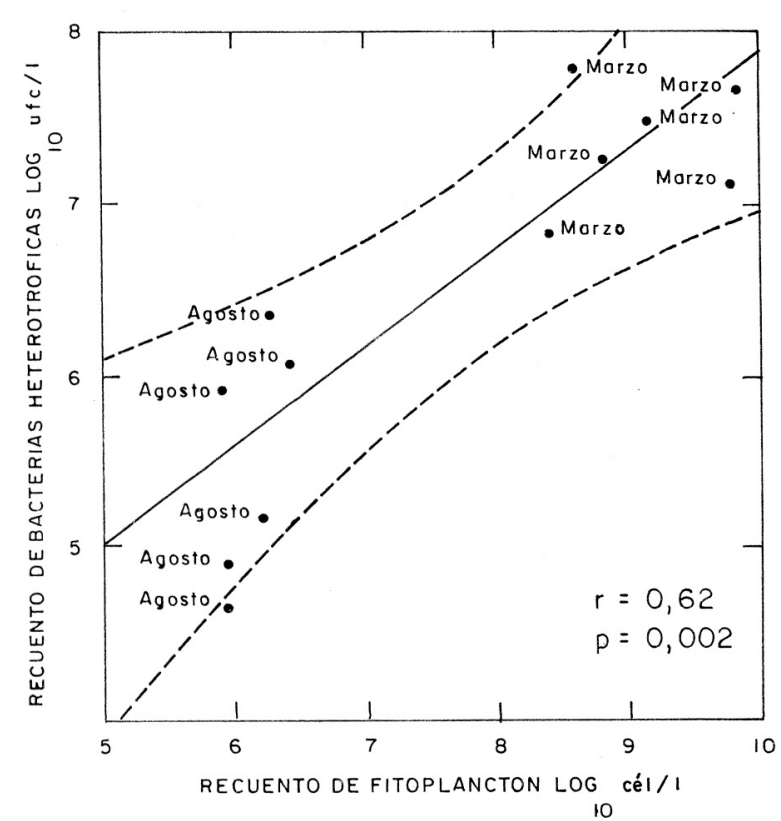

Figura 8. Relación entre el recuento de fitoplancton y de bacterias heterotróficas en aguas superficiales del Golfo de Arauco (recta de regresión e intervalo de confianza al $90 \%$ ).

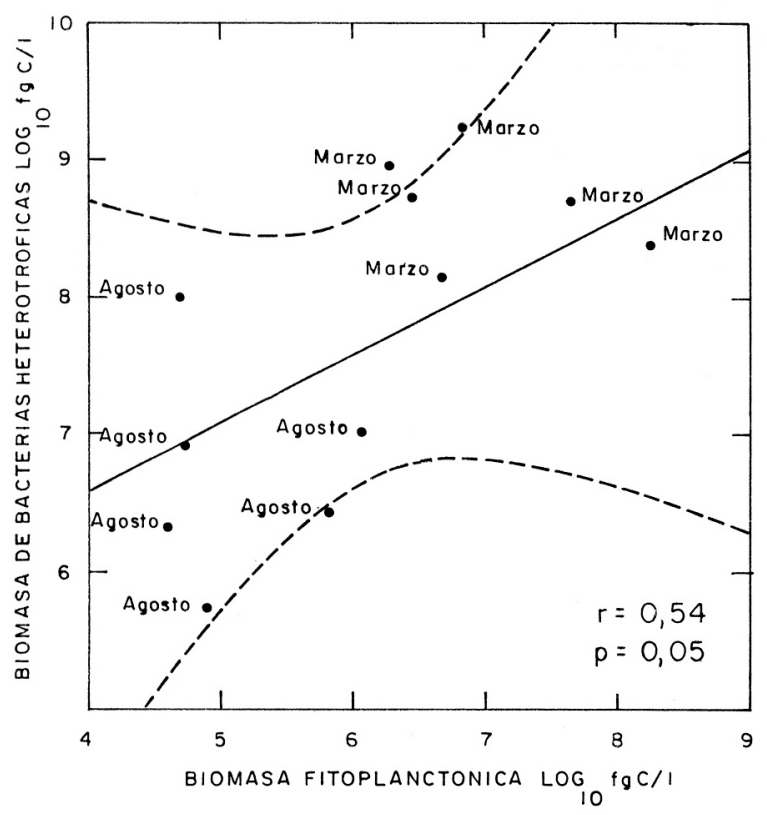

Figura 9. Relación entre la biomasa de fitoplancton y de bacterias heterotróficas en aguas superficiales del Golfo de Arauco (recta de regresión e intervalo de confianza al $90 \%$ ).

esta relación adquiere un modelo particular para cada estación del año.

Aunque los recuentos de bacterias heterotróficas

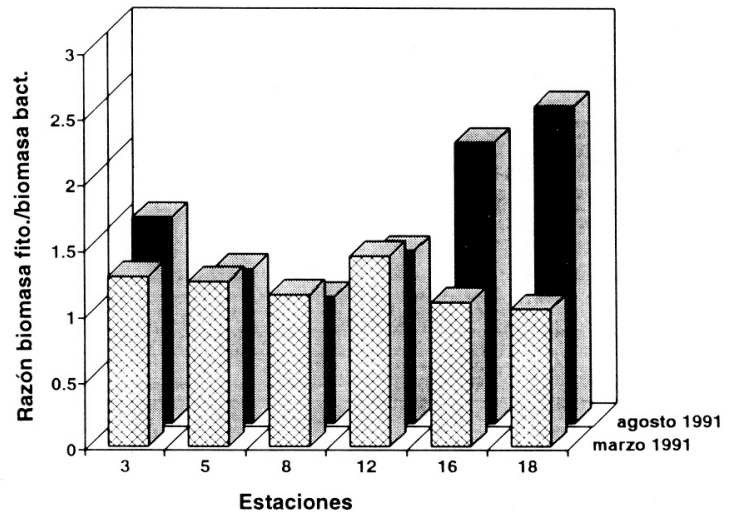

Figura 10. Razón entre la biomasa de fitoplancton (fito.) y del bacterioplancton (bact.) por estación de muestreo y mes.

no representan más del $10 \%$ del recuento total, es de esperar que sea éste el grupo más asociado al fitoplancton, por la producción de materia orgánica que implica la presencia del primer nivel trófico en el ecosistema. Se ha demostrado que un gran porcentaje de la productividad bacteriana proviene de los productos de excresión del fitoplancton (Azam et al., 1983; Coveney, 1982; Iturriaga y Zsolnay, 1983; Nalewajko y Lean, 1972).

El exudado de substancias orgánicas del fitoplancton activo y la oferta de carbono proveniente del fitoplancton muerto, son las principales fuentes de materia orgánica para las bacterias heterotróficas. Estas bacterias transforman substratos complejos a formas más fáciles de utilizar por otros organismos heterotróficos, dando una continuidad al flujo del carbono en el ambiente acuático (Sundh, 1992; Malone y Ducklow, 1990). Estos antecedentes corroboran la relación encontrada entre las bacterias heterótrofas y el fitoplancton (Tabla 1).

Es factible que una fracción del bacterioplancton de aguas superficiales presente un metabolismo quimolitotrófico, las que junto a bacterias oligoheterotróficas no son recuperables en los medios de cultivos utilizados en este trabajo. Todas estas comunidades son detectadas en un recuento total mediante microscopía de epifluorescencia, lo que podría explicar la ausencia de relación entre el recuento de fitoplancton y el del total bacteriano, considerando además que este recuento no discrimina entre bacterias vivas y muertas.

La matriz de correlación entre variables ambientales y biológicas sugiere que la temperatura influ- 
ye en la abundancia del fitoplancton y de bacterias heterotróficas, y la concentración de fosfato sólo sobre la abundancia del fitoplancton (Tabla 2). Se ha observado que el metabolismo fitoplanctónico y bacteriano generalmente se incrementa con el aumento de la temperatura, dentro de cierto rango (Lynch y Poole, 1979). Además, la fijación de carbono fotosintético depende no sólo de la población fotoautotrófica, sino que también de las condiciones ambientales, tales como disponibilidad de nutrientes, intensidad de luz y temperatura (Lynch y Poole, 1979).

En una segunda etapa de análisis se determinó el grado de relación de cada parámetro con un conjunto dado de parámetros ambientales. Para ello se utilizó el análisis de regresión múltiple paso a paso (Sokal y Rohlf, 1988), siguiendo las sugerencias de Fry (1982) para investigar cambios en las comuni- dades microbianas en términos de variables ambientales.

Los análisis de regresión múltiple entre la biomasa y recuentos del fitoplancton y bacterioplancton heterotrófico con las variables físicas y químicas consideradas, indican que aproximadamente el $92 \%$ de la variación de la abundancia del fitoplancton es explicada por los cambios en la relación temperatura y $\mathrm{PO}_{4}$. El resto de los parámetros biológicos son explicados significativamente sólo por la temperatura (Tablas 3 y 4$)$.

La acción de la temperatura como variable íntimamente ligada a la actividad bacteriana es conocida (Rheinheimer, 1980; Grant y Long, 1989). En ambientes acuáticos se ha determinado la significativa correlación $(\mathrm{p}<0,05)$ de la temperatura con la abundancia y áctividad del bacterioplancton heterotrófico (Newbold et al., 1981). Bott (1975), Bell (1982) y

Tabla 1. Matriz de correlación entre la abundancia y biomasa bacteriana y fitoplanctónica en aguas superficiales del Golfo de Arauco (marzo y agosto 1991).

\begin{tabular}{|l|c|c|c|c|c|c|}
\hline & LFAB & LFBIOM & LRECTB & LRECH & LBIOMTB & LBIOMH \\
\hline LFAB & 1 & & & & & \\
LFBIOM & $0,74^{*}$ & 1 & & & & \\
LRECTB & $-0,50$ & $-0,32$ & 1 & & & \\
LRECH & $0,79^{*}$ & 0,49 & $-0,26$ & 1 & & \\
LBIOMTB & 0,35 & 0,12 & 0,24 & 0,44 & 1 & \\
LBIOMH & $0,85^{*}$ & $0,73^{*}$ & $-0,31$ & $0,99^{*}$ & 0,53 & 1 \\
\hline
\end{tabular}

$\begin{array}{lll}\text { LFAB } & : & \log _{10} \text { abundancia de fitoplancton } \\ \text { LFBIOM } & : & \log _{10} \text { biomasa de fitoplancton } \\ \text { LRECTB } & : & \log _{10} \text { recuento total bacteriano } \\ \text { LRECH } & : & \log _{10} \text { recuento de bacterias heterótrofas } \\ \text { LBIOMTB } & : & \log _{10} \text { biomasa total bacteriana } \\ \text { LBIOMH } & : & \log _{10} \text { biomasa de bacterias heterótrofas } \\ * & : & \text { valores significativos }(\mathrm{p}<0,05)\end{array}$

Tabla 2. Matriz de correlación entre variables ambientales y biológicas.

\begin{tabular}{|l|c|c|c|c|c|}
\hline & \multicolumn{5}{|c|}{ Parámetros físicos y químicos } \\
\cline { 2 - 6 } & $\mathrm{O}_{2}$ & $\mathrm{~T}^{\circ}$ & $\mathrm{NH}_{4}^{+}$ & $\mathrm{NO}_{3}$ & $\mathrm{PO}_{4}$ \\
\hline Abundancia de fitoplancton & 0,16 & $0,94^{*}$ & $0,66^{*}$ & $-0,28$ & $0,78^{*}$ \\
\hline Biomasa de fitoplancton & 0,03 & $0,80^{*}$ & 0,35 & $-0,27$ & 0,57 \\
\hline Abundancia de bacterias heterotróficas & $0,36^{*}$ & $0,78^{*}$ & 0,56 & $-0,22$ & 0,48 \\
\hline Biomasa de bacterias heterotróficas & 0,34 & $0,81^{*}$ & 0,56 & $-0,27$ & 0,57 \\
\hline
\end{tabular}

* : valores significativos $(p<0,05)$ 
Kaminski y Fenoni (1980). determinaron que el bacterioplancton psicrófilo que habita aguas de $10^{\circ} \mathrm{C}$ presenta un óptimo crecimiento cuando la temperatma aumenta a unos $20-25^{\circ} \mathrm{C}$.

Cabe hacer notar que. de acuerdo a lo observado en la estación 8 con respecto a las otras estaciones. la influencia delóo Bío-Bío en el sector de la desembocadura estaría afectando negativamente los recuentos de bacterias totales en marzo. Como no se presenta la misma situación en los recuentos de bacterias heterotróficas, se deduce que el efecto negativo es principalmente sobre bacterias autóctonas y que gran parte del recuento total de ese mes estaría representado por bacterias heterotróficas, entre las que se encuentran las alóctonas traídas por el río. Por otra parte, la abundancia de fitoplancton presenta el mayor valor en marzo en la estación 8, la más afectada por la pluma delóo en esta temporada, que presentó un desplazamiento de la capa superficial hacia el sur. Esta llegada de agua del río implica un aumento de nutrientes en dicha zona, favoreciendo ef desarrollo del fitoplancton.

La razón entre la biomasa de fitoplancton y la de bacterias heterotróficas varía a lo menos en dos órdenes de magnitud entre algunas estaciones (Fig. 10). Se puede observar que el comportamiento de esta relación tiene una tendencia más homogénea en marzo y notoriamente más alta en las estaciones 16 y 18 en agosto.

Tomando en cuenta la ubicación de las estaciones 16 y 18 (Fig. 1), se podría postular que éstas representan un sector del Golfo que recibe menor influencia de la desembocadura del río Bío-Bío. Esto sugiere que la dinámica funcional del bacterioplanctoo heterotrófico es diferente en la zona más alejada de la desembocadura y que ella es marcadamente influenciada por la estacionalidad.

De los resultados de este trabajo se desprende la importancia de profundizar en estudios de interacción entre microalgas y bacterias en aguas del Golfo de Arauco, tanto a escala temporal como espacial, incluyendo determinaciones de productividad primaria y potencial heterotrófico. Esto con el propósito de contribuir a entender el movimiento del carbono en las microbiocenosis de la columna de agua.

Tabla 3. Varianzas de las variables biológicas explicadas por los parámetros físicos y químicos.

\begin{tabular}{|c|c|c|c|c|c|c|c|}
\hline & & \multicolumn{6}{|c|}{ Parámetros físicos y químioos } \\
\hline & & $\mathbf{O}_{2}$ & $\mathbf{T}^{\mathbf{o}}$ & $\mathrm{NH}_{4}^{+}$ & $\mathrm{NO}_{3}$ & $\mathrm{PO}_{4}$ & $\%$ VE \\
\hline $\mathbf{I}$ & Abundancia de fitoplancton & ns & * & ns & ns & * & 92 \\
\hline II & Biomasa de fitoplancton & ns & $*$ & ns & ns & ns & 64 \\
\hline III & $\begin{array}{l}\text { Abundancia de bacterias } \\
\text { heterotróficas }\end{array}$ & ns & $*$ & ns & ns & ns & 60 \\
\hline IV & $\begin{array}{l}\text { Biomasa de bacterias } \\
\text { heterotróficas }\end{array}$ & ns & $*$ & ns & ns & ns & 60 \\
\hline
\end{tabular}

Tabla 4. Modelos obtenidos por análisis de regresión múltiple.

\begin{tabular}{|l|ll|}
\hline I & $\log _{10}$ cEl & $=0,728\left(\mathrm{~T}^{\circ}\right)+0,985\left(\mathrm{PO}_{4}\right)-8,11 \quad(\mathrm{P}=0,001)$ \\
\hline II & $\log _{10} \mathrm{Pg} /$ & $=0,659\left(\mathrm{~T}^{\circ}\right)-4,428(\mathrm{P}=0,001)$ \\
\hline III & $\log _{10}$ ufd & $=0,549\left(\mathrm{~T}^{\circ}\right)-5,880(\mathrm{P}=0,003)$ \\
\hline IV & $\log _{10} \mathrm{fg} /$ & $=0,681\left(\mathrm{~T}^{\circ}\right)-6,687(\mathrm{P}=0,001)$ \\
\hline
\end{tabular}




\section{REFERENCIAS BIBLIOGRAFICAS}

American Public Health Association. 1980. Standard methods for the examination of waters and wastewater. American Waters Association and Waters Pollution Control Federation, $15^{\text {th }}$ Edition APHA, Washington D.C.: 10-211.

Arrizaga, A., J. Chong y C. Oyarzún. 1991. Evolución de las principales pesquerías de la V1lI Región: la pesquería del Golfo de Arauco. In: Gestión Ambiental de los Recursos Hídricos Continentales y Marinos, y Planificación Territorial. v.A. Gallardo (Ed.), Proyecto EULA: $27-$ 29.

Azam, F., T. Fenchel, J.G. Field, J.S. Gray, L.A. Meyer-Reil y F. Thingstad. 1983. The ecological role of waters-column microbes in the sea. Mar. Ecol. Prog., Ser. 10: 257-263.

Barcina, l., B. Ayo, M. Unanve, L. Egea y J. Iriberri. 1992. Comparison of rates of flagellate bacteriovory and bacterial production in marin coastal system. Appl. Environ. Microbiol., 58 (12): 3850-3856

Bell, C.R. 1982. Correlations between predominant heterotrohic bacteria and physiochemical water quality parameters in two Canadian rivers. Appl. Environ. Microbiol., 43(3): 269-283.

Bott, T.L. 1975. Bacterial growth rates and temperature optima in a stream with a fluctuating thermal regime. Limnol. Oceanog., 20: 191-197.

Coveney, M. 1982. Bacterial uptake of photosynthetic carbon from freshwater phytoplankton. Oikos, 38: 8-20.

Fry, J.C, 1982. The analysis of microbial interaction and comunities in situ. In: Microbial Interactions and Communities. A.T. Bull and J.H. Slater (Eds.), Academic Press, London, 1: 103-154.

Fry, J.C. 1988. Determination ofbiomass. In: Methods in Aquatic Bacteriology. B. Austin (Ed.), John Wiley and Sons, 425 pp.

Fuhrman, L. 1991. Bacterioplankton roles in cycling of organic matter: a microbial food web uptake. In: Brookhaven National Laboratory Symposium, Plenum Press, 1: 1-22.
Grant, W.D. y P.E. Long. 1989. Microbiología am biental. Ed. Acribia, Zaragoza, España, 221 pp.

Iturriaga, R. y A. Zsolnay. 1983. Heterotrophic uptake and transformation of phytoplankton extracellular products. Bol. Mar., 26: 375-381.

Kaminski, J.S. y G.D. Ferroni. 1980. Growth of psicrophilic and mesophilic aquatic bacterial isolates at the environmental temperature. Water Research, 14: 815-820.

Lynch, J.M. y N.J. Poole. 1979. Microbial ecology: a conceptual approach. Blackwell Scientific Publications.

Malone, T.C y H.W. Ducklow. 1990. Microbial biomass in the coastal plume of Chesapeake Bay: Phytoplankton-bacterioplankton relationsh ips. Limnol. Oceanogr., 35(2): 296-312.

Nalewajko, C. y D.R. Lean. 1972. Growth and excretion in planktonic algae and bacteria. J. Phycol., 8: 361-366.

Newbold, J.D., J.W. Elwiid, R.V. O'Neill y W. Van Winkle. 1981. Measuring nutrients spiraling in streams. Can. J. Fish. Aq. Sci., 38: 860-863.

Parsons, T.R., Y. Maita y C.M. Lalli. 1984. A manual of chemical and biological methods for seawater analysis. Pergamon Press, 173 pp.

Rheinheimer, G. 1980. Aquatic microbiology. John Wiley and Sons, 225 pp.

Sokal, R. y F. Rohlf. 1988. Biometría: principios y métodos estadísticos en la investigación ecológica. Biometrycs, M.L. León (Trad.), Málaga, España, 859 pp.

Sundh, I. 1992. Biochemical composition of dissolved organic carbon derived from phytoplankton and used by heterotrophic bacteria. Appl. Environ. Microbiol., 58(9): 2938-2947.

UNEP. 1988. Standard chemical methods for marine environmental monitoring. Reference Methods for Marine Pollution. UNEP/IOC/IAEA,Studies $\mathrm{N}^{\circ} 50$.

Utermöhl, H. 1958. Zur vervollkommung der quantitativen phytoplankton methodick. Mil. Inl. Verein. Limnol., 9: 1-38. 